\title{
Miscegenation and Intimacy
}

\author{
VALERIE COOMS \\ UNIVERSITY OF WESTERN SYDNEY
}

\section{Fiona Probyn-Rapsey}

Made to Matter: White Fathers, Stolen Generations

Sydney University Press, Sydney, 2013

ISBN 781920899974 RRP AUD\$25.00

Fiona Probyn-Rapsey's Made to Matter: The White Fathers of the Stolen Generation focuses on a broad range of issues in relation to the politics of miscegenation and the lived experience of racial mixing. Drawing on the perspectives of Aboriginal descendants of white fathers, Probyn-Rapsey also discusses interracial relationships from the perspective of white husbands and fathers of Aboriginal children.

While Probyn-Rapsey starts with an account of Guess Who's Coming to Dinner? (dir. Stanley Kramer, 1967), the Hollywood social problem film centred on Sidney Poitier as an African-American man in a relationship with a white woman, the major focus of the book is the often undeclared relationships between white men and Aboriginal women in historical frontier and rural settings in Australia. By focusing on the oral histories and lived experiences of both Aboriginal and non-Aboriginal people in relation to associations between white men and Aboriginal women, Made

\section{ISSN 1837-8692}

Cultural Studies Review 2015. ๑ 2015 Valerie Cooms. This is an Open Access article distributed under the terms of the Creative Commons Attribution 4.0 Unported (CC BY 4.0) License (https://creativecommons.org/licenses/by/4.0/), allowing third parties to copy and redistribute the material in any medium or format and to remix, transform, and build upon the material for any purpose, even commercially, provided the original work is properly cited and states its license. 
to Matter delves into the secrets of colonial history, including the hidden sexual exploitation of Aboriginal women and girls. Much of this history is well known and discussed within Aboriginal families but perhaps only tacitly understood within white families and the historical societies that maintain and promote regional history.

As Made to Matter is keen to acknowledge, many Aboriginal people have written about the relationships shared between Aboriginal women and white men. Steve Kinnane has delved into the role that the settler colonial mindset played in shaping associations between Aboriginal women and white men. Aileen MoretonRobinson has focused on white women's role in the oppression of Aboriginal women. Drawing on personal experience, Bob Randall has illuminated the ways in which white men were incorporated into Aboriginal kinship systems as a means of acknowledging their relationships with Aboriginal women. Like Randall, Sally Morgan writes as the child of a mixed-race relationship. ${ }^{1}$ In my own work, I use the experience of growing up with an Aboriginal mother and a white father to approach the wider landscape of discrimination in postwar Australia.

Probyn-Rapsey's study is at its best when it brings out the impact of various government policies on the day-to-day lives of Aboriginal families. It shows how successive administrations grappled with the relationships between white men and Aboriginal women in different ways. Some attempted to keep white men and Aboriginal women apart, while others set out to 'regulate and not separate' Aboriginal children from their white fathers. (4) There were also attempts to ensure white men financially supported their children but the recognition of paternity (and its legal consequences) was always complicated by the prevailing attitude that only 'low Western whites would cohort with Aboriginal women'. (10) While some white men made applications to the Protectors of Aborigines for permission to marry Aboriginal women and some openly offered to support their Aboriginal children, the cruel reality was that if a child was categorised as being mixed race and living among Aboriginal people he or she could run the risk of being removed from their Aboriginal mother.

Probyn-Rapsey also explores the effects of successive policies that arose in relation to the twentieth century belief that it was possible to breed the colour out of Aboriginal people. Removing mixed-race Aboriginal children from their families and 
'blending' them into white society was seen by some governments to address the colonial fear of being outnumbered by mixed race people. Similarly, having Aboriginal women married off to white men of good character, as categorised by officials, removed the responsibility of governments to protect Aboriginal women from the perils associated with colonisation, including sexual exploitation.

One of the interesting points made in Made to Matter is that the blending of 'white blood' into Aboriginal people also bred 'Aboriginal blood' into white society. As Probyn-Rapsey highlights, this arguably sets the scene for all those stories in which the Aboriginal side of the original family is 'lost' then invariably recovered decades later when family genealogies can be enriched by such historical discoveries. (139) The policy of breeding out the colour not only highlights ignorance of the depths of Aboriginal society, kinship and culture, but also supported the colonial fantasies such as the belief that a race of people who appeared white but had Aboriginal blood in their veins would be more suited to hard work in tropical climates. This misconception about race conveniently informed the development of northern Australia, where prohibiting and discouraging sexual relationships between white men and Aboriginal women had proven impossible.

Probyn-Rapsey's discussion of these issues draws from the work of Aboriginal scholars like Jackie Huggins, Irene Watson, Steve Kinnane, Sally Morgan, Marcia Langton and Aileen Moreton-Robinson, as well as their white contemporaries (in particular Anna Haebich, Ann McGrath and Ann Curthoys). She also draws, somewhat less persuasively, from a band of postcolonial theorists who speak less to the specificities of Australian Indigenous experience. Importantly, Probyn-Rapsey uses both cultural and theoretical arguments to put to bed the misconception that Aboriginality is related to the colour of a person's skin. She also highlights the ways in which phrases such as 'one sixteenth Aboriginal' are employed to query and dispute Aboriginality or the genetic mathematician's view that Aboriginality should be denied past the 'octoroon'. $(43,87)$

Made to Matter also describes the disdain accorded to 'combos', a term given to white men who openly lived with Aboriginal women and mixed with Aboriginal communities. These figures were shunned not merely because they consorted with Aboriginal women but also because they 'found degrees of mutuality and equality 
between black and white'. (89) Branded as 'black sheep', they came under diverse forms of scrutiny from white family members and social critics, but, as Marcia Langton has argued, they also point toward a postcolonial space of 'mutuality and equality' that might counter-pose the colonial nightmare of violence, denial and segregation. (88-9)

Made to Matter draws on accounts by Aboriginal people of their relationships with their white fathers. Steve Kinnane recalls the terms used for white men, like his father, who 'consorted' with Aboriginal people and were dismissed as 'degenerates' or 'isolates'. (46) Bob Randall's autobiography Songman describes how his white father had multiple children to five Aboriginal wives, all of whom continue to share strong kinship ties though linkage to a common white ancestor. (85-6) Randall goes on to explain the complex affiliations established by white men taking Aboriginal women as wives and the reciprocal relationships these created between white and Aboriginal families. Randall also notes, however, that when reciprocal obligations between these families were not fulfilled much conflict arose. In relation to these obligations and the potential for their being unmet in contexts that continue to be distorted by the ongoing effects of racism and colonisation, Probyn-Rapsey invokes Aileen Moreton-Robinson's account of the 'different politicisation of Aboriginal and white interactions and the broader epistemological and cultural issue of the limits to knowing an "other" be they black or white'. (86)

Probyn-Rapsey makes the interesting observation that when white men mixed or lived with Aboriginal women, they saw themselves as being transformed in the encounter rather than being the transformers of Aboriginal people. This captures the experiences of Bill Harney, a white man who openly lived and worked with Aboriginal people and had a relationship with an Aboriginal woman. As well as holding Aboriginal culture in high regard, Harney was also one of the most 'prolific writers of the twentieth century'. (46) Harney frankly describes the ways in which white men who openly married Aboriginal women were treated badly by other white men, many of whom secretly conducting sexual relationships with Aboriginal women and denied their mixed-race children.

Made to Matter is at its best when it analyses the complexities within relationships between white men and Aboriginal women and the larger communities from which they come. Probyn-Rapsey draws on Daryl Tonkin's 
recollections about being seen as a 'villain' because he chose to live with his Aboriginal wife, their children and their extended family'. (96) While such men were sometimes seen as 'heroic anti-racists' by Aboriginal people, they were not viewed well by their own families or community. (102) Tonkin describes how his disapproving sister played a role in 'keeping Aboriginal people in their place'. But, as Aileen Moreton-Robinson suggests, white women were often the monitors of race and class lines within white families partly as a means of addressing their own structural disadvantage. First-wave feminists, she writes, 'sought to civilize Indigenous women, in particular our sexuality, to minimize racial impurity and ... maximise their own status within the white nation by reproducing whiteness'. (146) The book also quotes Matt Savage's much franker appraisal of the tension between white wives and the husbands who abandoned them for Aboriginal women: 'Every one of these blokes went back to the lubras. And the wives hated them for it.' (146) In the case of my parents, it was my mother rather than my father who suffered discrimination due to their mixed-race marriage, or at least it was she who spoke about it, particularly about her struggle with the racism of my father's family.

Drawing on Aboriginal life-writing and other forms of non-traditional scholarship, Made to Matter expands our thinking about the way segregation and sexual intimacy are correlated. Men, such as Bill Harney, who openly conducted relationships with Aboriginal women and cared for their mixed-race children, were critical of those 'who pretended not to associate with Aboriginal women, or accorded no value to them and their relationships'. (95) White men who conducted relationships with Aboriginal women in secret and did not acknowledge their Aboriginal children were called Jim Crows. According to Probyn-Rapsey, Jim Crow men 'were capable of extreme cruelty, confident (however nervously) that their own transgressions would be covered over by their public performance of segregation'. (109) The book explores the effects of this governing sexual hypocrisy that meant generations of white men could discriminate and enforce segregation by day and pursue Aboriginal women at night. As Bill Stanner is quoted as saying, 'persistent indifference' towards Aboriginal people was a major feature, if not the defining feature, of European life in Australia, though this indifference has also been used to mask sexual exploitation-and sexual love-between white and Aboriginal people. (110) 
Made to Matter goes a long way towards exposing the complexities of the sexual relationships between white men and Aboriginal women together with the exploitation of Aboriginal women and girls. Discussion of the exploitation of Aboriginal women includes noting the prevalence of rape and the arrangements that were made for Aboriginal girls to be traded as 'sexual currency'. (118) Once again, in the absence of historical records about these unacknowledged practices, ProbynRapsey turns to Aboriginal women's memoirs and first-person accounts of the sexual abuse young Indigenous girls often endured.

In taking the lid off these unmentioned histories, Probyn-Rapsey is forced to press into service terms such as 'a state of unknowing', 'disremembering' or 'denial'. She underscores Steve Kinnane's point about the disassociative structure that made it possible for white fathers to act 'as if they saw the children of their unions with Aboriginal women as not being connected to themselves'. (111) As Kinnane argues, this 'puzzling disconnect' between some white men and their Aboriginal children encapsulates a more general 'state of indifference' that is cultivated on both personal and impersonal levels. Where Kinnane argues that this distancing seems not to have been motivated by feelings like hatred alone, or even fear or guilt, Probyn-Rapsey speculates that this state of 'numbed indifference ... positioned white men as, on the one hand, spermatic conduits for future whiteness and, on the other hand, as the white nation's black sheep, degenerate sons who threatened the very legitimacy of white colonial authority'. (111) The ambivalent position accorded these men is related to the experience of Aboriginal people who knew their white relatives were watching but not acknowledging them (119)

In openly analysing the 'Great Australian silence' and 'cults of disremembering', that surround sexual intimacy between white Australians and Aboriginal people, Made to Matter breaches the uncomfortable reality of colonial history. Probyn-Rapsey also touches briefly on later 'coming together' of Aboriginal and non-Aboriginal people at public gathering places such as swimming pools, cinemas, hospitals, cafes and streets in Australian townships. (122) While Aboriginal people had formerly been excluded, marginalised, threatened or cordoned off from such spaces, the weakening of social segregation made these spaces central to 'nervous landscapes' in which unacknowledged relatives might come together. 
(123) While Aboriginal families knew about their white relatives, white families were keen to continue to avoid the truths of miscegenation, particularly in public.

Made to Matter deals with colonial amnesia around miscegenation and reconciles Aboriginal accounts with a broader history of silence, denial, injustice and abuse. Probyn-Rapsey is also exemplary in acknowledging that without the accounts and analyses of the past provided by Aboriginal writers and academics Australian cultural history will remain incomplete. This book uniquely demonstrates how much Aboriginal people know and understand about white families, their tensions and secrets. While this knowledge refers to the broader categories of race, gender and colonisation, it also remains a deeply personal knowledge grounded in the lived experience of mixed-race intimacies.

Valerie Cooms belongs to the Nunukul people of North Stradbroke Island in Queensland and is currently chairperson of the Quandamooka Yoolloburabee Registered Native Title Body Corporate. Valerie completed a PhD on Aboriginal policy and resistance in Queensland in the years 1965 to 1975 and has recently published an essay about growing up with a Aboriginal mother and a white Communist father in Ann Curthoys and Joy Damousi (eds), What Did You Do in the Cold War, Daddy? Stories from a Troubled Time (2014).

\section{-NOTES}

1 Bob Randall, Songman: The Story of an Aboriginal Elder of Uluru, ABC Books, Sydney 2003; Sally

Morgan, My Place, Fremantle Arts Centre Press, Fremantle, 1998.

\section{-BIBLIOGRAPHY}

Randall, B., Songman: The Story of an Aboriginal Elder of Uluru, ABC Books, Sydney 2003.

Morgan, S., My Place, Fremantle Arts Centre Press, Fremantle, 1998. 